abnormalities and the risk of thrombosis are reversed in polycythaemic patients by therapeutic phlebotomy. The liver is the main site for clearing plasminogen activator, ${ }^{1+}$ and in the absence of antiplasmin this may account for the localisation of thrombus formation in the hepatic outflow. Thrombocytosis is a common feature in myeloproliferative disorders, and platelet IgG Fc receptors may be activated in vivo by the high concentrations of circulating immune complexes found in these disorders. ${ }^{1516}$ The raised concentrations of plasma $\beta$ thromboglobulin and the high incidence of clinical thromboses are both reduced by prophylaxis with aspirin. ${ }^{1015}$

There is also a high incidence of thrombosis in systemic lupus erythematosus and an associated reduction in endothelial cell synthesis of prostacyclin ${ }^{17}$ and vasculitis. DNA antibodies are found in about a tenth of patients with myelofibrosis, ${ }^{18}$ and a vasculitis affecting small vessels has also been described. ${ }^{19}$ It remains to be established, however, whether these observations are important in the aetiology of thrombosis in chronic myeloproliferative disorders. Another feature that has been seen in a few patients with myelofibrosis is the paroxysmal nocturnal haemoglobinuria syndrome. ${ }^{20}$ This is another clonal haemopoietic stem cell disorder, which is more often associated with aplastic anaemia and acute leukaemia. Patients with paroxysmal nocturnal haemoglobinuria have a high incidence of intra-abdominal thrombosis, which is probably caused by complement induced platelet activation. 21 Paroxysmal nocturnal haemoglobinuria-like abnormalities found by the sucrose and cold antibody lysis tests $^{20}$ and activation of complement ${ }^{23}$ are also common in myelofibrosis, and thrombosis in chronic myeloproliferative disorders may therefore be linked to these abnormalities.

There are, therefore, several different explanations for the hepatic vein thrombosis seen in chronic myeloproliferative disorders. The development of thromboses in patients with occult disorders suggests that previously overlooked mechanisms may be important. Different mechanisms may be at work in different patients, and each may require different treatment strategies.

Senior Lecturer in Haematology,

B J BOUGHTON

University of Birmingham,

Birmingham B15 2TT

1 Reid CD, Chanarin I, Lewis J. Formes frustes in myeloproliferative disorders. Identification by the growth of an endogenous erythroid clone in patients with arterial vascular disease. Lancet 1982;i:14-6.

2 Valla D, Casadevall N, Lacomb C. Primary myeloproliferative disorder and hepatic vein thrombosis. A prospective study of erythroid colony formation in 20 patients with Budd Chiari syndrome. Ann Intern Med 1985;103:329-34.

3 Pagliuca A, Mufti GJ, Tahernia JM, el al. In vitro colony culture and chromosomal studies in hepatic and portal vein thrombosis - possible evidence of an occult myeloproliferative state. $Q \mathcal{F}$ Med 1990;76:981-9.

4 Wasserman LR, Gilbert HS. Surgery in polycythemia vera. $N$ Engl f Med 1963;269:1226.

5 Kessler CM, Klein HG, Havlik RJ. Uncontrolled thrombocytosis in chronic myeloproliferative diseases. Br f Haematol 1982;50:157-67.

Mason JE, De Vita VT, Canello GP. Thrombocytosis in chronic granulocytic leukemia. Incidence and clinical significance. Blood 1974;44:483

Gilbert HS. Definition, clinical features and diagnosis of polycythaemia vera. Clinics in Haematology 1975;4:263-90.

8 Pearson TC, Wetherley-Mein G. The course and complications of idiopathic erythrocytosis. Clin Lab Haematol 1979;1:189-96.

MacDougall BR, McMaster P, Calne RY, Williams R. Survival and rehabilitation after orthotopic liver transplantation. Lancet 1980;i:1326-8.

10 Gilbert HS, Hanna MM. Low dose aspirin/low hematocrit regime: a safe and effective treatment for polycythemia vera [Abstract]. Blood 1986;68 (suppl 1):770.

11 Pearson TC, Wetherley-Mein G. Vascular occlusive episodes and venous haematocrit in primary proliferative polycythaemia. Lancet $1978 ; i i$ 1220-2.

2 Boughton BJ, Dallinger KJ. 'I I fibrinogen turnover in polycythaemia; the effect of phlebotomy. Brf Haematol 1983;53:97.

13 Biorkman SE, Laurel CB. Serum proteins and fibrinolysis in polycythaemia vera. Scand f Clin Lab Invest 1956;8:304.

4 Brozovic M. Acquired disorders of coagulation. In: Bloom AL, Thomas DP, eds. Haemostasis and thrombosis. Edinburgh: Churchill Livingstone, 1987:519-34.

15 Boughton BJ, Allington MJ, King A. Platelet and plasma $\beta$-thromboglobulin in myeloproliferative syndromes and secondary thrombocytosis. Br $\mathcal{F}$ Haematol 1978;40:125.

16 Baglin TP, Price SM, Boughton BJ. Circulating high molecular weight $\operatorname{lgG}$ complexes in myeloproliferative disorders. F Clin Pathol 1990;43:102-5.

17 Carreras LO, Defryn G, Machin SJ. Arterial thrombosis, intrauterine death and lupus anticoagulant. Detection of immunoglobulin interfering with prostacyclin formation. Lancet $1981 ; \mathrm{i}: 244-6$.

18 Rondeau E, Seligny SS, Dhermy D, et al. Immune disorders in agnogenic myeloid metaplasia: relations to myelofibrosis. Br $\mathcal{F}$ Haematol 1983;53:467-75.

19 Singh AK, Wetherley-Mein G. Microvascular occlusive lesions in thrombocytopenia. $\mathrm{Br} \mathcal{F}$ Haematol 1977;36:553.

20 Catovsky D, Lewis SM, Sherman D. Erythrocyte sensitivity to in vitro lysis in leukaemia. $\mathrm{Br} \mathcal{F}$ Haematol 1971;21:451.

21 Rosse WE. Paroxysmal nocturnal haemoglobinuria. In: Clinical immunohaematology. Oxford: Blackwell Scientific, 1990:593-648.

22 Shrieber AD. Paroxysmal nocturnal hemoglobinuria revisited. N Engl f Med 1983; 109:723-5.

23 Gordon BR, Coleman M, Parirorkhe K, Norbibi KD. Immunologic abnormalities in myelofibrosis with activation of complement. Blood 1981;58:904-10.

\title{
Second malignant tumours in head and neck cancer
}

\section{Commoner than elsewhere}

Although advances in surgical repair, radiotherapy, and chemotherapy have improved control of cancer of the head and neck, ${ }^{12}$ these improvements have hardly influenced survival. $^{3-5}$ One of the main reasons for this failure is the development of second malignant tumours, which occur more commonly in the head and neck than in any other site..$^{6-8}$ Among patients with head and neck cancer more are alleged to die from second tumours than from their original disease. ${ }^{36}$ Despite recent interest in second tumours little is known about risk factors and in particular about the influence of treatment of the first primary tumour on development of a second.

Several workers have tried to assess the influence of TNM stage, sex, site, and behavioural characteristics on the development of second malignant tumours. The risk of a second primary tumour is thought to be independent of the stage of the first ${ }^{79}$ and seems to be no greater in men than in women, ${ }^{10}$ but whether it is influenced by the site of the primary tumour remains controversial. ${ }^{79}$ The greatest risk, however, seems to be continued use of alcohol and tobacco, though opinion varies about which is more influential. Wynder et al found tobacco but not alcohol to be associated with an increased risk." They also found, however, that stopping both smoking and drinking did not prevent further tumours from developing, although Moore showed a decreased incidence when smoking ceased. ${ }^{12}$ Moore also noted a greater risk of second malignant tumours with continued smoking, ${ }^{13}$ although Castigliano did not. ${ }^{14}$ Others have found that smoking and drinking together seem to increase the risk of second malignant tumours. ${ }^{791516}$ Thus, although smoking and drinking may increase the risk, stopping smoking and drinking do not seem to remove it.

The increased interest in second malignant tumours has not been matched by an equally critical appraisal of the effect of treatment on the primary lesion. Most squamous carcinomas of the head and neck region are managed with surgery, radiotherapy, or a combination of both. Most studies have not clearly distinguished between the numbers of second tumours arising after surgical treatment of the primary tumour and after radiotherapy. ${ }^{68917-23}$ Those that have recorded them separately have made little or no attempt to correlate this with the extent of disease at the time of initial treatment, ${ }^{7} 0^{1124-28}$ although one study found that the risk of second malignant tumours was independent of the stage of the disease. ${ }^{9}$ 
Moreover, the length of follow up has varied widely among the studies. There are also great difficulties in comparing surgery and radiotherapy. Not all patients are screened for other primary tumours at the time of initial treatment, so a second tumour might be wrongly attributed. Furthermore, the longer patients survive the more likely they are to develop another tumour. ${ }^{67}$

The few studies that have tried to assess the effect of treatment suggest no significant difference between radiotherapy and surgery within five years after treating the primary tumour. ${ }^{1028}$ For example, over five years Parker and Enstrom found that 11 out of 678 surgically treated patients and 22 out of 1473 irradiated patients developed second primary tumours. ${ }^{10}$ Beyond five years, however, the incidence of second malignant tumours seems to be higher in those who received radiotherapy. ${ }^{7112426}$ For example, among 535 patients with laryngeal carcinoma followed up for five to 25 years, second primary tumours occurred in $3.9 \%$ of those treated by surgery and $9 \%$ of those treated with radiotherapy. ${ }^{24}$ Such tumours do not, however, always occur in previously irradiated sites.

Recently we have shown that normal oral mucosa exposed to ionising radiation during the treatment of orofacial tumours displays abnormal DNA profiles. ${ }^{29}$ Although these returned to the normal diploid state within six weeks after completing treatment, the potential for latent radiation damage remains..$^{30-32}$ This may explain why after five years the incidence of second malignant tumours seems to be greater in those who received radiotherapy. The fact that children and adolescents exposed to irradiation show a predisposition to neoplasia in the head and neck ${ }^{33-36}$ invites suspicion that the same may be true for adults exposed to radiotherapy. Yet another factor is the potential interaction between radiation damage and continued use of tobacco or alcohol. These potential causal factors for oral cancer might act as promoters of any radiation induced damage and hence give rise to more mucosal abnormalities.

The tumour itself may exercise an effect on the regional mucosa. Slaughter et al first described the concept of field cancerisation, ${ }^{37}$ and recent research using exfoliative cytology has identified evidence for field change within the normal oral mucosa of patients with oral cancer even in those who do not smoke or drink alcohol. ${ }^{38}$ If that is so then radiotherapy has a greater potential to treat the surrounding mucosa than surgical excision.

Difficult though it would be, an attempt should be made to establish the relative risk for second malignant tumours of one form of treatment over another. At the very least TNM classification, age, smoking and drinking habits, method of treatment, and development of further tumours within five and 10 years should be recorded.

The promise shown by certain retinoids in preventing neoplastic change ${ }^{39}$ seems to be confirmed by recent reports, ${ }^{12}$ but their inability to affect local, regional, or distant recurrence is disappointing and should prompt further study into the effect of all treatment strategies.

Clinical Lecturer,

GRAHAM R OGDEN

Department of Dental Surgery,

Dundee Dental Hospital and School,

Dundee DD1 4HR

1 Hong WK, Lippman SM, Itri LM, et al. Prevention of second primary tumors with isotretinoin in squamous cell carcinoma of the head and neck. $N$ Engl f Med 1990;323:795-801.

2 Meyskens FL. Coming of age - the chemoprevention of cancer. N Engl f Med 1990;323:825-7.

3 Jesse RH, Sugarbaker EV. Squamous cell carcinoma of the oropharynx: why we fail. Am $\mathcal{F}$ Surg 1976;132:435-8.

4 Stell PM, McCormick MS. Cancer of the head and neck: are we doing any better? Lancet 1985 ;ii: 1127.

5 Easson EC, Palmer MK. Prognostic factors in oral cancer. Clin Oncol 1976;2:191-202.

6 Carr RJ, Langdon JD. Multiple primaries in mouth cancer - the price of success. Br $\mathcal{F}$ Oral Maxillofac Surg 1989;27:394-9.

7 Cooper JS, Pajak TF, Rubin P, et al. Second malignancies in patients who have head and neck cancer: incidence, effect on survival, implications based on RTOG experience. Int f Rad Oncol Biol Phys 1989;17:449-56.

8 Kotwall C, Razack MS, Sako K, Rao U. Multiple primary cancers in squamous cell cancer of head and neck. I Surg Oncol 1989;40:97-9.

9 Licciardello JTW, Spitz MR, Hong WK. Multiple primary cancer in patients with cancer of the head and neck: second cancer of the head neck esophagus and lung. Int $\mathcal{F}$ Rad Oncol Biol Phys 1989;17:467-76.

10 Parker RG, Enstrom JE. Secondary cancer following primaries of head and neck. Int $\mathcal{f}$ Rad Oncol Biol Phys 1988;14:561-4.

11 Wynder EL, Dodo H, Bloch D, Gantt RC, Moore OS. Epidemiologic investigation of multiple primary cancer of the upper alimentary and respiratory tracts. Cancer 1969;24:730-9.

12 Moore C. Smoking and cancer of the mouth, pharynx and larynx. JAMA 1971;218:553-8.

13 Moore C. Smoking and cancer of the mouth, pharynx and larynx. FAMA 1965;191:283-6.

4 Castigliano SG. Influence of continued smoking on the incidence of second primary cancers including mouth, pharynx and larynx. $\mathcal{F}$ Am Dent Assoc 1968;77:580-5.

5 Hsairi M, Luce D, Point D, et al. Risk factors for simultaneous carcinoma of the head and neck. Head Neck 1989;11:426-30.

16 Schottenfeld D, Gantt RC, Synder EL. The role of alcohol and tobacco in multiple primary cancers of the upper digestive system, larynx and lung - a prospective study. Prev Med 1974;3:277-93.

17 Marchetta FC, Sako K, Camp F. Multiple malignancies in patients with head and neck cancer. Am f Surg 1965;110:537-41.

18 Cohn AM, Peppard SB. Multiple primary malignant tumor of the head and neck. Am $\mathcal{F}$ Otolaryngol 1980;1:411-7.

19 Maisel RH, Vermeersch H. Panendoscopy for second primaries in head and neck. Ann Otol Rhinol Laryngol 1981;90:460-4.

20 Wagenfeld DJH, Harwood AH, Bryce DP, van Nostrand AWP, de Boer G. Second primary respiratory tract malignancy in supraglottic carcinoma. Arch Otolaryngol 1981;107:135-7.

21 Deviri E, Bartal A, Goldsher $M$. Occurrence of additional primary neoplasm in patients with laryngeal carcinoma in Israel. Ann Otol Rhinol Laryngol 1982;91:261-5.

22 Gluckman JL, Crissman JD. Survival rates in 548 patients with multiple neoplasms of upper aerodigestive tract. Laryngoscope 1983;93:71-4.

23 Hordjik GJ, de Jong JMA. Synchronous and metachronous tumours of head and neck. $\mathcal{F}$ Laryngol Otol 1983;97:619-21.

24 Lawson W, Som M. Second primary cancer after irradiation of laryngeal cancer. Ann Otol Rhinol Laryngol 1975;84:771-5.

25 Seydel HG. Risk of tumor-induction following radiation therapy. Cancer 1975;35:1641-5.

6 Brown RG, Poole MD, Calamel PM, Bakamjian VY. Advanced and recurrent squamous carcinoma of the lower lip. Am f Surg 1976;132:492-7.

27 Weaver A, Fleming SM. Triple endoscopy: a neglected essential in head and neck cancer. Surgery 1979;86:493-6.

28 Shons AR, McQuarroe DG. Multiple primary epidermoid carcinomas of the upper aerodigestive tract. Arch Surg 1985;12:1007-9.

29 Ogden GR, Cowpe JG, Green MW. Effect of radiotherapy on oral mucosa assessed by quantitative exfoliative cytology. $\mathcal{F}$ Clin Pathol 1989;42:940-3.

30 Storm HH. Second primary cancer after treatment for cervical cancer: late effects after radiotherapy. Cancer 1988;61:679-88.

31 Modan B, Mart M, Baidatz D. Radiation induced head and neck cancers. Lancet 1974;i:277-9.

32 Walker KE, Leibel SA, Wara WM. Squamous cell carcinoma of the head and neck after radiation therapy for Hodgkin's disease. Cancer 1985;56:1052-5.

33 Martin H, Strong E, Spiro RH. Radiation-induced skin cancer of the head and neck. Cancer 1970;25:61-71.

34 Southwick HW. Radiation-associated head and neck tumors. Am $\mathcal{H}$ Surg 1977;134:438-43.

35 DeGroot LJ, Reilly M, Pinnameneni K, Refetoff $S$. Retrospective and prospective study of radiation-induced thyroid disease. $A m \mathcal{F}$ Med 1983;74:852-62.

36 Sirota DK, Eden AR, Biller HF. Multiple head and neck neoplasia following radiation for benign disease during childhood. $\mathcal{F}$ Surg Oncol 1988;38:101-3.

37 Slaughter DP, Southwick HW, Smejkal W. Field cancerization in oral stratified squamou epithelium. Cancer 1953;6:963-8.

38 Ogden GR, Cowpe JG, Green MW. Evidence of field change in oral cancer. Br $\mathcal{f}$ Oral Maxillofac Surg 1990;28:390-2.

39 Hong WK, Endicott J, Itri LM, et al. 13 Cis-retinoic acid in the treatment of oral leukoplakia. NEnglf Med 1986;315:1501-5. 